\title{
ESTUDOS CORÂNICOS E TRADUÇÃO: O TEXTO ORIGINAL
}

\author{
Michel Sleiman 1 \\ 1-Universidade de São Paulo, São Paulo, São Paulo, Brasil
}

\begin{abstract}
Resumo: A recente e significativa contribuição de estudos sobre as origens do islão e do Alcorão, assinados por estudiosos europeus e americanos, tem trazido para o campo dos estudos corânicos a necessidade de reavaliar a compreensão quanto à materialidade sígnica do texto corânico, com base em métodos de edição e interpretação conhecidos dos estudos bíblicos. Este ensaio retoma as linhas gerais de alguns desses estudos sublinhando as implicações deles na redefinição do texto original e a necessidade de a retradução incluir tais pressupostos.

Palavras chave: Estudos Corânicos; Métodos de Interpretação; Crítica Corânica; Tradução do Alcorão
\end{abstract}

\section{QURANIC STUDIES AND TRANSLATION: THE ORIGINAL TEXT}

\begin{abstract}
The recent and significant contribution of studies on the origins of Islam and the Quran, signed by European and American scholars, has brought to the field of Quranic studies the need to reassess understanding of the signic materiality of the Quranic text, based on adopted editing and interpretation methods of Bible studies. This essay takes up the outline of some of these studies by underlining their implications for the redefinition of the original text and the need for retranslation to include such assumptions.
\end{abstract}

Keywords: Quranic Studies; Interpretation Methods; Quranic Criticism; Quran Translation 


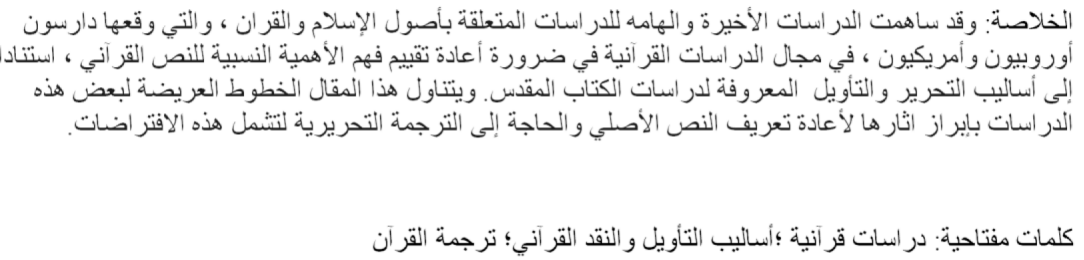

A tradução de trechos do Alcorão para outras línguas, depreende-se, foi um recurso usado bastante cedo no islão, seja pelas cartas enviadas pelo Profeta aos governantes de outros reinos conclamando-os a aderirem à nova ordem divina, cartas essas que seriam lidas nas línguas de seus destinatários copta, persa, etíope, bizantino, seja pelo episódio em que um de seus companheiros, Ja'far Ibn Abi Talib (m. 629), refugiado na Etiópia em 616, lê parafraseando (?) a um rei Negus muito interessado a Sura de Maria (surat maryam), em conhecido episódio que lhe angariou, para sua sorte, além da empatia do governante africano cristão, a proteção incondicional deste contra os emissários coraixitas que ali buscavam deportá-lo a Meca (Ibn Ishaq 152) ${ }^{1}$. Na mesma linha, um século e meio após a morte do Profeta, a recitação da Sura de Abertura (surat alfatiha), para efeitos de oração durante os ofícios nas mesquitas, fora realizada nas mais diversas línguas dos conversos por recomendação, acatada por um tempo, do imã iraquiano Abu Hanifa (m. 767), esse que posteriormente será tomado como o pai da escola hanafita, uma das quatro escolas de jurisprudência do islão sunita (Abdul-Raof 91-92).

Já para finais do século VIII, a ortodoxia abássida apressa-se a fechar de vez as portas para a possibilidade/legitimidade de tradução do Alcorão. Para efeitos teológicos, e mesmo proselitistas, valerá somente o texto árabe plasmado em sua irrevogável forma naquela altura dos 800 , e para daí em diante. É quando entra em cena

\footnotetext{
1 Ver informações relativas nos ensaios sobre a biografia do Profeta, disponíveis em tradução brasileira, de D. S. Margoliouth e de M. Lings, resenhados respectivamente por J. de S. Alves e S. E. Alwan.
} 
o fenômeno da interpretação corânica entendida como um ato de tafsir, uma "explicação", portanto, explicação balizada pelos ulemás com base em um aparato que subordina a gramática do texto corânico - em todos os seus níveis: morfológico, sintático, lexical, prosódico - às versões um pouco mais contextuais de alguns dos episódios da vida do Profeta. São os chamados livros de siras e hadices, reunidos, em todo caso, por homens de reconhecida fé; são coleções de citações e máximas sapienciais, morais, e relatos pios, hagiografias, entenda-se, mais que biografias. Os ulemás explicam o versículo, do claro ao mais obscuro, recorrendo a uma aludida transmissão oral tida como ininterrupta, uma cadeia de transmissão que leva a palavra corânica até o testemunho tanto quanto possível de quem presenciou a Revelação em seu tempo: os anos 610 a 632. A tradução que se admitirá com o tempo passará a ser a tradução dos significados que constem nos livros de tafsir, mais do que da letra propriamente do Alcorão.

Quando em tempos modernos se cogitou aplicar o ta'wil, algo como uma interpretação racional, intuitiva e pessoal, a proposta foi veementemente rechaçada e seu autor acusado de heresia e perseguido de morte ${ }^{2}$. O problema parece ser a concepção mesma do que se entende ser a tradução. Não é incomum que estudiosos contemporâneos nossos encontrem inexorabilidade, ou "lacunas" na imperfeita ou mesmo impossível reprodução letra a letra do texto corânico em outra língua. É o que se depreende da assertiva de Abdul-Raof (92):

\section{O discurso do Alcorão é um cenário linguístico caracteriza- do por um arco-íris de características sintáticas, semânticas, retóricas, fonéticas e culturais diferentes de outros tipos de discurso árabe. Através da coalizão dessas características,}

\footnotetext{
${ }^{2}$ Sobre a biografia e o estudo corânico relegado de Nasr Hámid Abu Zayd (19432010), confira o estudo resumido de N. Kermani, realizado com base em seu Offenbarung als Kommunikation. Das Konzept wahy in Nasr Hamid Abu Zayds' Mafhum al-Nass, Frankfurt am Main, 1996. Ver, adiante, outra menção nossa a Abu Zayd.
} 
uma textura linguística única se desdobra para o leitor dominada pela harmonia nos níveis sintático, semântico e prosódico: de fato, a interfertilização entre esses elementos não poderia ser melhor alcançada. A maioria desses recursos é estranha às normas linguísticas de outras línguas. ${ }^{3}$

É como se a tradução devesse mimetizar por uma só e única palavra cada voz semântica e lexical árabe, espelhar estruturalmente a sintaxe e o estilo, os procedimentos retóricos, as referências culturais. Na impossibilidade da tradução como um selo timbrado a reproduzir tal original, caberá ao tradutor, na perspectiva da tradição islâmica, a tarefa de dizer na nova língua o que os comentaristas do islão clássico disseram ser, em seu tempo - e para sempre - a letra do divino livro.

Há uma inflexão, no entanto, nesse discurso... Não sendo o Alcorão, por dogma religioso, obra criada por humanos e, inescapavelmente, não tendo outra autoria senão Deus, o livro sagrado dos muçulmanos não pertence, em princípio, senão a toda a humanidade, pois transcende a proposição que lhe credita a religião guardiã, a de ser uma das fontes base para a formulação da religião islâmica.

Aceitando-se ser Deus o seu autor, o Alcorão pode ser visto como uma de Suas criações; é, portanto, um sinal divino - uma aya, diz-se em árabe. $\mathrm{O}$ versículo - também aya, em árabe - é um sinal divino assim como o é - permita-se a analogia - a montanha gigante ou a minúscula formiga, o homem racional e a flor ou o arbusto; lado a lado, o portentoso e o ínfimo; do sutil ao sensível, tudo é dado como obra Sua.

\footnotetext{
${ }^{3}$ Tradução nossa de: “Qur'anic discourse is a linguistic scenery characterized by a rainbow of syntactic, semantic, rhetorical, phonetic and cultural features that are distinct from other types of Arabic discourse. Through the coalition of these features, a unique linguistic texture unfolds to the reader dominated by harmony on the syntactic, semantic and prosodic levels: in fact interfertilisation among these elements could not be better achieved. Most of these features are alien to the linguistic norms of other languages".
} 
Concebido pelo homem, porém, o sistema de fé que se ergue coloca-se como um produto do artifício. Humano, o sistema é construção e, em sendo, gera legislação que vale para as "coisas do mundo". É da legislação do sistema religioso que o livro fundante da religião deva ser zelado pelos ditos homens da fé, que definem o legítimo e o falsário com base nos fundamentos que tradicionalmente o sistema adota a partir de sua fonte: no caso da religião islâmica, e no entender de sua tradição, o Alcorão é essa fonte, como a Bíblia o é para as religiões cristãs e a Torá, elemento que compõe o mosaico de fé do judaísmo. Há um sentido tautológico nisso tudo: o livro - fonte - cria o fim - referência, e esta elege o acerto e o erro no deciframento da fonte. Tal é a versão tradicional da religião.

A ortodoxia, sunita como xiita, tem por dogma que o Alcorão é a fala direta de Deus descida à humanidade por intermédio da voz do anjo Gabriel ouvida pelo Profeta. Em determinado momento de Seu livro, Deus lembra aos humanos o que dissera à humanidade, séculos antes, outro enviado Seu, 'Isà b. Maryam (Jesus filho de Maria): "Filhos de Israel, eu sou o enviado de Deus [vindo] a vós em confirmação da Torá que tenho em mãos e em anunciação de um enviado que virá depois de mim, Mais-Louvado (ahmad) é o nome dele" (Alc. 61, 6). Ora, esse nome Ahmad teria sido, segundo a tradição, o próprio nome do Profeta antes que os fiéis passassem a referi-lo, a partir de algum momento, por Muhammad, o que significa "muito louvado". Para a tradição, a filiação que ora se possa atribuir ao livro corânico, seja quanto a nomes, episódios ou espiritualidades que constem das outras escrituras de Deus, a Torá ou o Evangelho, só é corretamente feita pelo próprio Autor, O-Deus, al[i]lah: Ele mesmo, Quem re-conhece e estabelece no ato de Sua fala a linearidade de Seu monoteísmo. A palavra divina na revelação árabe é um Critério (furqan). Não deriva de outras escrituras, mas corrige essas mesmas, discerne-as, evocando-as alteradas, por zikr "lembrança", na versão como Deus as entende e atualiza em língua árabe clara (mubin).

Não há intertextualidade, portanto, não há história genética que vincule o Alcorão a outros livros existentes. A tradição alega que 
o livro muçulmano é a única palavra inalterada d'Ele, guardada sem máculas pelos homens, através da ação insuspeita de um registro inicial feito por escrito por um e outro companheiros do Profeta, escrito esse, de todo modo, revisado por ele e imediatamente memorizado por guardadores fieis que ao longo dos séculos engendraram uma cadeia ininterrupta de testemunhas auriculares remontáveis até o primeiro registro da Mensagem.

Mais porosos à ação humana e... do tempo, os livros bíblicos do judaísmo e do cristianismo - escrituras decerto inspiradas por Deus a seus profetas e homens santificados - livros sagrados, portanto, porque relatam o sagrado, desde os tempos da Reforma, porém, têm sido objeto de revisões, o que tem forçado, sem aparentes grandes prejuízos para a fé, o reexame de suas leituras. Um mesmo método de crítica histórico-filológica ${ }^{4}$ - seguido mais recentemente pelo método retórico-intertextual ${ }^{5}$ - , aplicado ao texto corânico começa a se insinuar a partir de meados do século XIX - nem sempre no mesmo ritmo, seja dito - e revigora-se nas últimas décadas ainda que, praticamente, em mãos de estudiosos de escolas europeias, sobretudo alemã e inglesa ${ }^{6}$, permanecendo a revisão do texto corânico assunto tabu entre os estudiosos da matéria residentes em países de maioria islâmica, muçulmanos ou não; é coibida, a bem dizer, e, quando menos, rechaçada. Nesse sentido, um caso emblemático é o do intelectual Nasr Hámid Abu Zayd, professor da Universidade do Cairo, que, acusado de apostasia (que ele sempre negou) nos anos 1990, teve o matrimônio anulado pela Corte do Egito - com base em que um apóstata não pode permanecer casado com uma muçulmana - vindo a exilar-se na Holanda, onde atuou

${ }^{4} \mathrm{Cf}$. a respeito desse método A. N. Lopes e L. F. Xavier.

${ }^{5} \mathrm{Cf}$. a respeito desse método R. Meynet (Traité e La rhétorique).

${ }^{6}$ Desde Abraham Geiger, Theodor Nöldeke, Siegmund Fraenkel, Karl Vollers e Ignaz Goldziher (apresentado por Aleksander Jovanovic em Tiraz 1), cujos estudos cobrem o século XIX até a Segundo Guerra, até a retomada vigorosa da matéria nos anos 1970 por John Wansbrough, seguido pelas recentes contribuições de Christoph Luxenberg, passando por Michael Cook, Patricia Crone, Carlos Andrés Segovia, Olivier Hanne, entre outros. 
como professor-pesquisador convidado da renomada Universidade de Leiden. Morto em 2010, seu corpo foi enterrado no vilarejo de Kuhafa, cidade onde nasceu, que fica na província egípcia de Tanta.

Em resumidas linhas, pode-se dizer que para o método histórico-filológico a edição oficial da mesquita egípcia de Alazhar, de 1924, que hoje circula entre nós, pode não ser tão fiel ao livro original que estaria bem refletido na recensão feita por ordem do califa bem-guiado Osmã (644-656), o terceiro na linha sucessória após a morte do Profeta em 632, livro aquele de cujas cópias restaria ao menos uma, "incompleta", guardada em museu do Uzbequistão. Incinerados os materiais que serviram de base para a recensão de Osmã, as cópias enviadas às principais províncias subordinadas ao poder califal foram feitas na incipiente ortografia hijaziana de uma trintena de anos após a morte do Profeta. Atente-se também à consideração da crítica atual quanto a ser o califa omíada Abdel Malik (646-707), quem governou em Damasco em seus últimos vinte anos de vida, o provável promotor da mais antiga recensão legada; seria ele quem eliminara as cópias de outras versões de texto corânico que ainda circulavam à sua época. $\mathrm{O}$ mesmo califa é quem enfrentou com vitória o império bizantino, tendo cunhado as primeiras moedas com inscrição árabe, primeiramente sem referência corânica nelas e logo mais sim, que seriam adotadas em toda a extensão dos territórios conquistados pelo novo poder ascendente ${ }^{7}$.

${ }^{7}$ Ver a esse respeito a opinião de M. A. Amir-Moezzi (44-74), professor da École des Hautes Études e pesquisador do londrino Institute of Ismaili Studie. Ver também obra dirigida por ele e D. de Smet. Segundo A-L de Prémare (Fondations, 294-301, 461-462), contudo, apoiado nos escritos do polímata do século IX Alkindi (citados em Georges Tartar, Dialogue islamo-chrétien sous le calife alMa'mûn (813-834). Les épîtres d'al-Hâsimî et d'al-Kindî, doctorat de 3e cycle, sous la dir. de T. Fahd, Strasbourg, 1977: 117 e 190. Estudo não consultado por nós), tal ação do califa omíada Abdel Malik deve ser tributada, na verdade, à iniciativa do então poderoso governador do Iraque, o muito letrado Alhajjáj Ibn Yusuf, de quem se diz impusera um primeiro (?) sistema de vocalização ao antigo texto osmaniano, enviando as novas cópias aos afamados centros da cultura da época e eliminando em seguida as antigas cópias feitas por ordem do califa Osmã (m. 656) - à revelia do próprio califa Abdel Malik - muito embora mais tarde, já 
Ao lado de uma transmissão oral tributada a memoriões de diferente localidade (e admitidas, em consenso, as divergências entre elas), tal escrita seria a base de transmissão do livro corânico que foi sendo posteriormente copiado e difundido numa ortografia progressivamente aperfeiçoada até os albores do século IX, mas já nas cidades iraquianas dos abássidas, sobretudo na hoje finda Kufa e em Bagdá; no tempo em que a língua árabe vê definidas as pautas de sua gramática, tempo em que se escrevem comentários ao mesmo Alcorão e se editam, bem como se comentam, as biografias sobre o Profeta (siras), de circulação ainda oral, mas também se registram os seus feitos e ditos (hadices), assim como toda a alegada literatura árabe de tempo prévio e coetâneo ao Alcorão, acompanhada dos comentários feitos pelos mesmos gramáticos e recenseadores ${ }^{8}$. O árabe antigo até os tempos do anúncio corânico - e durante um bom tempo depois dele, como se presume - dependeu daquela mesma escrita incipiente para o seu suporte e veículo material, quando não alheia, caso se aceite a tese de que os versículos do Alcorão, ou alguns deles, tenham sido conhecidos, em algum estágio, em escrita siríaca, antes da recensão de Osmã feita na mencionada

no período abássida, tenham sido alegadamente eliminadas as cópias desse mesmo Alhajjáj. Tal é a incerteza que ronda a data da que teria sido a "primeira" ou "a mais antiga" recensão que existe do livro corânico.

${ }^{8}$ Cópias manuscritas do Alcorão, contendo indicação escrita de data, nos chegam a partir dessa época. A mais antiga nesse sentido é a cópia que pertenceu a Amajur, governador de Damasco a serviço dos abássidas, e a data escrita é 264 da Hégira, ano 877-878 da nossa era. No mesmo período têm entrada os livros do gênero historiográfico khabar, "notícias", sobre eventos que aconteceram em vida do Profeta e durante as conquistas que se seguiram à sua morte, escritos por autores como o iraquiano nascido em Kufa, Sayf b. 'Umar (m. 796-7), Ibn Sa'd (m. 845) e Ibn Chabba (m. 876); seguidos pelas coleções de hadices, estando entre as primeiras, a de Bukhari (m. 870); e finalmente os comentários ao Alcorão, do gênero tafsir, sendo o mais completo dentre os pioneiros o do iraniano Attabari (m. 923). Um estudo de referência da língua árabe clássica é o do gramático persa Sibawayh (c.760-796). Por sua vez, as recensões comentadas da literatura pré-islâmica e a descrição de sua métrica se iniciam na segunda metade do século VIII, com o persa Hammad Arrawiya e do sularábico, radicado em Bassora, Khalil b. Ahmad Alfarahidi (m. 791). 
escrita hijaziana. Os estudos revisionistas (Hanne; Amir-Moezzi), especialmente os da modalidade "hipercrítica", aceitam que o Alcorão possa ter-se debuxado nos estandardizados caracteres aramaico-siríacos, ou mesmo que o livro tenha sido dado a Maomé em uma língua siríaca, nativa nos aglomerados urbanos da Península Arábica na altura dos 500-600 - neste caso, o Alcorão seria uma tradução num árabe que se pretende claro, porque "tornado claro" ${ }^{10}$. Aceitam também que as suras do Alcorão tenham evoluído desde uma série de récitas em siríaco-árabe (Mingana $)^{11}$, quiçá já num árabe antigo (Larcher) - récitas essas que acusam o sectarismo cristão siríaco-árabe, ou judeu-cristão, num entorno proto -islâmico -, até a formação de suras genuinamente diferenciadas que atendiam à necessidade de circunscrever a ética social de uma comunidade (sendo modelar a de Medina, a primeira) que se colocava como restituidora de umas formas de monoteísmo primordial hanif, de tipo ainda "pagão", pré-monoteista.... considerando-se,

9 Bastante polêmico, e assumido não raro por estudiosos ligados a igrejas cristãs, o tema, contudo, merece atenção quando a perspectiva é a da leitura histórico-filológica e mesmo a da retórico-intertextual. É o caso do estudo em dois volumes de E-M Gallez. A lista de autores que se guiam pela tese de origem judaico-cristã do texto corânico é bastante longa e clama por mais estudos de caso e aprofundamento. Citem-se as contribuições interessantes de J. Chabbi, A-L de Prémare (Aux origines). Para uma apreciação mais ampla do sistema de interdependência na gênese das várias formas de monoteísmo de Oriente e Ocidente, ver o inspirado estudo de E. González Ferrín.

10 "Tornado claro", ao invés do tão-só "claro", como geralmente se traduz o corânico mubin (de banalbayyana), é a interpretação dada por C. Luxenberg, 105108 e nota 137, com base no siríaco bwan/ban/bayyen, que significa "elucidar", "explicar", o que em latim quereria dizer intelligere, discernere fecit.

${ }^{11}$ É bastante aceita entre os revisionistas a tese do siríaco-iraquiano Alfons Mingana, pertencente à escola inglesa, quanto à "influência siríaca no estilo do Alcorão", com base na existência anterior de uma literatura litúrgica cristã, sem prejuízo de alguma judaica, em alguma forma de árabe antigo, haja vista a diferença de estilos entre o texto corânico - singular - e o restante da sempre discutível literatura árabe pré-islâmica e mesmo da de época posterior. Cf. também o trabalho pioneiro de A. Jeffrey. Ambos os estudos estão na base dos estudos revisionistas hoje em curso. 
aqui, a leitura que Theodor Nöldeke (6) fez, em 1860, do termo árabe corânico hanif que refere a espiritualidade do mítico Abraão, com base no siríaco hanpá, acepção reanimada recentemente pelo estudioso de identidade incógnita Christoph Luxenberg (55).

As relações intertextuais, e especificamente as interescriturárias entre o Alcorão e outros textos sagrados - em particular, entre ele e as escrituras bíblico-semíticas -, são um alvo recente dos estudos que começam a destacar a partir da publicação em 2007 do Traité de rhétorique biblique, de Roland Meynet, baseado em pressupostos da antiga hermenêutica. Dois anos depois, em 2009, o prêmio iraniano World Prize for Book of the Year é dado ao pesquisador belga Michel Cuypers, em reconhecimento de sua análise do Alcorão, que toma por base os níveis de organização do discurso presentes igualmente na composições bíblico-semíticas, que foram alvo ainda em 1942, no célebre Chiasmus in the New Testament do hermeneuta norte-americano Nils Willhelm Lund. A observação desse método ${ }^{12}$ permite pensar o texto do Alcorão como uma realização previsível como um todo nos pressupostos da retórica semítica, em oposição, por exemplo, à retórica grega.

A aproximação generalizada do texto corânico aos textos bíblicos em semítico, que se desenha num horizonte próximo - há que se levantar como hipótese de estudo - romperia com o modo como a tradição islâmica demarcou o começo e o fim dos versículos corânicos na escritura original, o que, definitivamente, esta não o faz: em algum momento, sim, estabeleceram-se, e marcaram-se, para efeitos de recitação e comentário as pausas internas e os limites do versículo para a boa e correta recitação (tajwid). Tal redefinição do versículo que o método dessa análise permite pensar poderia eventualmente endossar ou refutar com argumento semântico-discursivo a tese de fundo siríaco do árabe corânico, que o estudo do já citado Luxenberg (307-320) ensaia deslocando, em algum dos casos que foca, a palavra de um final de versículo para o começo

${ }^{12}$ Sobre o método de análise retórico-semítica, ver de M. Cuypers, Le Festin, também disponível em árabe e inglês, e The composition.

Cad. Trad., Florianópolis, v. 39, n $^{0}$ esp., p. 101-119, set-dez, 2019 
do próximo, ou, na outra direção, do começo de um versículo para o final do anterior, apoiado, por outro lado, em que o sentido de determinado termo que parece obscuro em árabe ganha melhor sentido se buscado no siríaco, especialmente nas passagens onde se notam conflito ou mesmo incompreensões entre os comentaristas islâmicos, desde os mais antigos ${ }^{13}$.

Em outras palavras, a aproximação dos métodos histórico-filológico e retórico-semítico (Cuypers, L'analyse) pode jogar nova luz sobre pontos ainda obscuros do Nobre Livro. Seria o caso, por exemplo, de considerar-se essa primeira manifestação literária seguramente em língua árabe como um descolamento da "reverberação siríaca" num ambiente de cultura fortemente monoteísta... lá onde os estudos árabes em geral apontam - sem grandes questionamentos - como predominante um politeísmo árabe de tipo animista (?), em torno do santuário da Caaba? ${ }^{14}$ Não será o caso, perguntamos, de se pensar Meca como uma sociedade cindida entre no mínimo dois grandes grupos: um denso de base monoteísta, ocupando a larga base piramidal daquela sociedade, e outro de base politeísta, ocupando a parte mais alta daquela estrutura... sendo o Profeta e seus seguidores elementos desestabilizadores daquele malequilibrado edifício, algo não tão diverso afinal do que ocorrera centúrias antes na estatização do cristianismo em Roma?

No estudo premiado de Cuypers (Festin), a sura 5, tida como a última na ordem de revelação do Alcorão, guarda uma contundente conotação testamentária da missão profética de Maomé, insisten-

${ }^{13}$ Atendo-se à leitura dos versículos 5-6, 14-15 e 18-19 da sura 96. Embora não a cite, em linhas gerais a leitura proposta desse autor está fortemente apoiada na leitura que detalha G. Lüling. Boa exposição do método histórico-filológico aplicável ao estudo do Alcorão se encontra em J. Wansbrough, Quranic, que recupera as discussões da escola alemã de finais do século XIX com a tese, agora, da gênese corânica num "meio sectário" que o autor expõe em The sectarian. As reações às suas teses estão resenhadas no artigo de $\mathrm{H}$. Berg.

${ }^{14} \mathrm{P}$. Crone e M. Cook veem inconsistência de a Caaba localizar-se em Meca, admitindo-a mais a Norte, em territórios da Síria. Ver da mesma P. Crone, Meccan trade. Sobre a islamização dos ritos em torno da Caaba, ver J. Chabbi (52-55). 
temente identificada por Deus, no Seu discurso nessa e noutras suras, como uma missão nunca desconectada das ações dos precedentes Jesus e Moisés ${ }^{15}$. A "Mesa Servida", como indica o título que a tradição atribuiu a essa sura, sequer descuida do simbolismo alusivo à última ceia do Cristo. Revelada em Medina, a poucos meses do falecimento do Profeta, a despeito de ser uma das mais longas suras do Alcorão, com as quais compartilha a feição geral de compreenderem versículos bastante longos e com predominância da vocação prescritiva, a sura 5 repete, para a concorrência de sentidos, uma similar organização discursiva característica daquelas primeiras reveladas em Meca, que têm extensões que vão de muito curtas a curtas e contêm, via de regra, versículos que vão também de muito curtos a curtos, estando em geral carregados de forte conotação interpelativa e concentrada força poética (Cuypers, Apocalypse).

Com efeito, Luxenberg (320, 323-325) chama a atenção para o fato de a última sura na ordem da revelação fechar o que lhe parece ser um ciclo de referências corânicas à liturgia cristã da eucaristia, presente já na Sura do Coágulo, que alberga, segundo a tradição, os primeiros versículos revelados ao Profeta (301-325). O filólogo alemão propõe como um sentido original do termo corânico iqtarib "aproxima-te”, presente no último versículo da Sura do Coágulo, o

15 Alc. 5, 3: lyawma 'akmaltu lakum dinakum wa-'atmamtu 'alaykum ni'mati wa-radaytu lakum al'islama dina "Hoje Eu completei-vos o credo e culminei-vos Minha Graça e alegrei-vos com um credo de paz”. Tradução e grifos nossos: os sublinhados salientam a repetição morfossemanticossintática que se observa nos três segmentos; os negritos salientam as repetições sonoras nos três segmentos; os primeiros segmentos repetem 8 sílabas e o terceiro amplia para 10, obtendo-se acréscimo de $25 \%$ - o versículo árabe tem 10 sílabas nos primeiros segmentos e 12 no terceiro, observando-se acréscimo no último em $20 \%$; semântica e culturalmente o sema "culminar" contém os semas "completar" e "por cima", contidos no árabe " "atmamtu 'ala" = "completei sobre"; no campo da filiação linguístico-religiosa, a progressão entre "credo", "Graça" e "credo de paz" marca o fim do ciclo da revelação com os acordos de paz entre Medina e Meca e demais localidades durante a expansão na Península Arábica empreendida sob a égide do Profeta. 
sentido que tem no siríaco cristão - ainda hoje - o tecnicismo litúrgico etqarrab, o mesmo sentido refletido no árabe yataqarrab que utiliza Abu-Alfaraj Alisfahani, do século X, no seu famoso Livro das Canções quando se refere ao poeta pré-islâmico 'Adi Ibn Zayd que fora à igreja de Hira liyataqarrab, isto é, "para tomar parte da celebração da Comunhão" e poder ver a amada Hind, filha do rei Annu'man III, soberano daquele reino cristão entre 580 e 602, à mesma época, portanto, em que viveu o Profeta.

O Alcorão, depreende a perspectiva majoritária dos novos orientalistas, vai chegando à plataforma do livro corpus, livro de textos que reelaboram a literatura profética, redefinidos, apologéticos e carregados de historicidade. Tal livro corpus advém de um lugar (uma instância, precisamente) em que um Livro em maiúsculo fora concebido nos termos miraculosos de uma revelação que é autoproclamada "descida dos céus", como nos diz Mraizika (1828), um óvni, um bólido caído em meio ao deserto, numa sociedade totalmente oral (logo ela que tem junto ao Profeta escrivãos versados em grego e persa), despreparada ortograficamente (isto sim, parece mesmo ter sido) para os caprichos de uma língua clara, perfeita e desvinculada de historicidade (?)... um livro descido em língua celestial, um Verbo (kalam) não encarnado, não gerado embora, contraditoriamente, ambiguamente, a Palavra (kalima) no 'Isa corânico (Jesus) parecesse ser palavra gerada, encarnada, no ventre de Maryam (Maria) - um Verbo que é língua e linguagem incriadas, puras e purificadoras; um Verbo, enfim, que é um parakletos, fechando-se analogamente o ciclo de um monoteísmo trinitário renitente, apesar de todo o esforço dos cristianismos unitários e deste islão unitarista, tão repetidamente sublinhado por todo o livro do Alcorão.

Na leitura do citado A-L de Prémare (Fondations 317-321), o Alcorão "livro" é um produto que a primeira tradição destaca da coleção maior que são os livros de hadice. Nesses, as palavras qala annabi "disse o Profeta" (nas tradições proféticas "nabawiyya", tidas como falas dele) e qala allah "disse Deus" (nas tradições santas "qudsiyya", tidas como inspiradas por Ele) marcam graus 
de desvinculação da palavra humana em relação à palavra divina inspirada - filtrada, dir-se-ia - por Deus. Os livros de hadice repercutem, portanto, a ação do homem profeta, enquanto no Alcorão os versículos que ali aportam buscam anular essa mesma ação, retirando da fala do profeta todo e qualquer efeito de vontade. Daí o imperativo divino qul "dize", que no Alcorão precede o versículo em que tem aparição um enunciador. A diferença entre uma tradição santa e um versículo corânico seria, nesse modo de compreender as coisas, tão-só a propriedade recitativa: beleza e acerto absolutos que concorrem à perfeição para alcançar-se o efeito arrebatador na recitação. Esse é o Milagre. Daí ser o Alcorão um qur'an (qeryan, em aramaico-siríaco), um recitativo. A consciência de graus acusa a ação humana, categorizadora, classificatória e, portanto, aberta para os trabalhos de "seleção de tradições" realizadas no tempo do Profeta e no tempo dos califas, seja no núcleo inicial árabepeninsular como progressivamente nos domínios convertidos na Palestina, Síria, Egito e Iraque.

A tradução do Alcorão - livro que se tornou efetivamente o legado de uma nova religião e uma nova síntese de cultura, em constante interação com outros sistemas de cultura e de fé - compreenderá descobrir, idealmente - por meta, portanto - as camadas de tal processo formativo-compositivo do corpus corânico; por outro lado, dispor essas camadas em retrospectiva relacional com as narrativas bíblicas, especialmente as semíticas, embora também não se deva descuidar os referenciais egípcio-copta e zoroástrico -iraniano. É uma tarefa, bem se vê, de precisar sentidos na densidade histórica dos referenciais. Um é o sentido auferido no tempo imediato da composição (610-632) que considera a realidade espaço-temporal em que estavam imersos os atores, outro é o que lhe confere a entrada no corpus de um versículo por urgência de algum califa (Omar, Osmã, Abdel Malik). Cabe à filologia e à crítica literária socorrerem o tradutor nessa "busca do texto original" durante a jornada de outra retradução do livro clássico.

Outra questão que se coloca a tradução: traduzir o Livro Sagrado não é dar um novo Alcorão. A tradução oferece um texto 
paralelo, dependente de seu par, esse que é seu ponto de partida, seu motor, sua razão de ser e existir. No entanto, o tradutor deve enfrentar o seu ato no campo do factível, da possibilidade, portanto. Traduzir é possível porque confere nova realidade a um texto definido em instância anterior, em disposição sígnica outra, mas completiva, com relação a ele no tempo e no espaço. Com ele a tradução pode estabelecer uma relação isomórfica, ou paramórfica, como a definiu tão insistentemente Haroldo de Campos (34): significados equivalentes, em relação de interdependência, produzidos por criação de estruturas diferentes. Ou, dito de outro modo, a tradução pode instaurar uma forma independente da original mas que se mostra capaz de manter com o texto anterior uma relação dialogal, na qual o tradutor reavalia significados de vária natureza: signos verbais, sonoros, prosódicos, culturais dispostos na pauta singular da língua da tradução. Um Alcorão em português é um texto que só faz sentido na língua portuguesa do tradutor, que a propõe, e do leitor, que a recodifica em sua subjetividade. Ora, era isso que os comentadores dos livros de Tafsir encadearam ao longo dos séculos: deram à antiga letra do Livro o sentido já perdido entre os novos leitores do Alcorão, eles mesmos incluídos. O comentador, ontem, fazia o papel do tradutor hoje (este, que tão pouco entende de um livro de tão profundo alcance); e o leitor ressignificava o comentário em sua subjetividade. Isto, enfim, é o que sempre quis dizer o temido conceito de $t a$ 'wil, interpretação servida de razão, intuição, subjetividade.

Os estudos corânicos revisionistas estão a dar ao tradutor uma nova tarefa: a de precisar os sentidos do livro a partir do que imaginou o autor, a geração desse autor, as gerações futuras que leram o texto daquele autor... e as gerações atuais. Mas de que autor tratamos aqui? Se é Deus, há que buscá-Lo o tradutor em todas as Suas manifestações, incluídas as anteriores. "Alif lam mim", diz o primeiro versículo da segunda sura: a letra do Alcorão, seja como for, tem começo, meio e fim, não necessariamente nesta ordem. 


\section{Referências}

Abdul-Raof, Hussein. "The Qur'an: limits of translatability (91-106), em Faiq, Said (ed.)". Cultural encounters in translation from Arabic. Clevedon, Buffalo, Toronto: Multilingual Matters Ltd., 2004.

Alves, Jemima de Souza; Margoliouth, David Samuel. "Maomé e a ascensão do Islã”. Tiraz 8, Ano VIII, 2016: 159-161. Tradução de Sérgio Lamarão. São Paulo: Contraponto, 2012.

Alwan, Sarah Elizabeth. Lings, Martin. "A vida do Profeta do Islam segundo as fontes mais antigas”. Tiraz 8, Ano VIII, 2016: 162-167. Trad. Cléris Nogueira, Luiz Pontual e Sérgio Rizek. São Paulo: Attar Editorial, 2010.

Amir-Moezzi, Mohammad Ali. The silent Qur'an and the speaking Qur'an. Scriptural sources of Islam between history and fervor. New York: Columbia University Press, 2016.

Amir-Moezzi, Mohammad Ali; Smet, Daniel de (dir.). Controverses sur les écritures canoniques de l'islam. Paris: Les Éditions du Cerf, 2014.

Berg, Herbert. "The implications of, and opposition to the methods and theories of John Wansbrough". Method and theory in the study of Religion, vol 9-1 (1997), 3-22, em Ibn Warraq (ed.) The quest for the Historical Muhammad, Nova York, Prometheus Books, 2000: 489-509.

Campos, Haroldo de. Da tradução como criação e como crítica. Metalinguagem \& outras metas: ensaios de teoria e crítica literária. $4^{\text {a }}$ ed. aum. São Paulo:

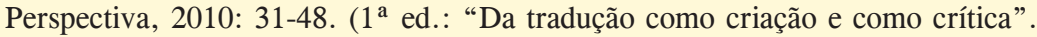
Tempo Brasileiro, 415, jun./set. 1967: 163-181).

Chabbi, Jacqueline. Le Seigneur des tribus. L'islam de Mahomet, Paris: CNRS, 2010 ( $1^{\text {a }}$. ed., Noesis, 1997).

Crone, Patricia. Meccan trade and the rise of Islam, Oxford: Basil Blackwell, 1987. 
Crone, Patricia; Cook, Michael. Hagarism. The making of the Islamic World. Cambridge: CUP, 1977.

Cuypers, Michel. Le Festin. Une lecture de la sourate al-Mâ'ida (Collection "Rhétorique sémitique" n³), Paris: Lethielleux, 2007.

Cuypers, Michel. The composition of the Qur'an. Rhetorical analysis, London, New York: Bloomsbury Academic, 2015.

Cuypers, Michel. A Qur'anic Apocalypse: a reading of the thirty-three last surahs of the Qur'an. Translation by Jerry Ryan. Manchester: Lockwood Express, 2018.

Cuypers, Michel. "L'analyse rhetorique face à la critique historique de J. Wansbrough et de G. Lüling. L'exemple de la sourate 96”. In: Segovia, Carlos A.; Lourié, Basil (eds.). The Coming of the Comforter: when, where, and to whom? Studies on the rise of Islam and various other topics in memory of John Wansbrough. Piscataway: Giorgias Press, 2012: 343-369.

Gallez, Edouard-Marie. Le Messie et son Prophète, 2 vol., Paris: Éditions de Paris, 2005 e 2010.

González Ferrín, Emilio. A angústia de Abraão. As origens culturais do judaísmo, do cristianismo e do islamismo. Trad. Pedro Lima Vasconcellos, São Paulo: Paulus, 2018.

Hanne, Olivier. "Le Coran à l'épreuve de la critique historico-philologique. Ecueils de l'hypercritique, impasses de la littéralité". L'hypercritique et le littéralisme dans la démarche historienne, Madalina Vartejanu-Joubert, Mar 2012, La Roche sur Yon, France. 28/06/2019. < halshs-01461158>

Ibn Ishaq, Muhammad. "Sirat rasul allah". In: Ibn Ishaq, Muhammad. The life of Muhammad. Trad. A. Guillaume. Oxford: Oxford University Press, 1955.

Jeffrey, Arthur. The foreign vocabular of the Qur'an. Baroda, 1938.

Kermani, Navid. From Revelation to Interpretation: Nasr Hamid Abu Zayd and the literary study of the Qur'an (169-192). Suha Taji-Farouki (ed.) Modern 
Muslim intellectuals and the Qur'an. Oxford: Oxford University Press / Institute of Ismaili Studies, 2004.

Larcher, Pierre. "Qu'est-ce que l'arabe du Coran? Réfléxions d'un linguiste”, Cahiers de linguistique de l'INALCO 5, 2003-2005 (années de tomaison), Linguistique arabe, éd. Georgine Ayoub et Jérôme Lentin, 2008: 27-47.

Lings, Martin. A vida do Profeta do Islam segundo as fontes mais antigas. Trad. Cléris Nogueira, Luiz Pontual e Sérgio Rizek. São Paulo: Attar Editorial, 2010.

Lopes, Augustus Nicodemus. "O dilema do método histórico-crítico na interpretação bíblica”. Fides reformata X, 1, 2005: 115-138. Impresso.

Lüling, Günter. A challenge to Islam for reformation. The rediscovery and reliable reconstruction of a comprehensive pre-Islamic christian hymnal hidden in the Koran under earliest islamic reinterpretations, XXXVII. Nova Delhi: Motilal Banarsidass Publishers, 2003 (trad. inglesa de Über den Urkoran. Ansätze zu Rekonstruktion der vorislamisch-christlichen Strophenlieder im Koran. $1^{\text {a }}$. ed. 1974).

Luxenberg, Christoph. The Syro-Aramaic reading of the Koran. A contribution to the decoding of the language of the Koran, Berlim: Verlag Hans Schiler, 2007.

Margoliouth, David Samuel. Maomé e a ascensão do Islã. Trad. Sérgio Lamarão, São Paulo: Contraponto, 2012.

Meynet, Roland. "La rhétorique biblique et semitique. État de la question". Retorica, 28, August 2010: 290-312. Research Gate. 28/07/2019. < https://www. researchgate.net/publication/259728537>

Meynet, Roland. Traité de rhétorique biblique, RhSem 4, Paris: Lethielleux, 2007.

Jovanovic, Aleksandar. "Goldziher, húngaro das Arábias". Tiraz 1, ano I, 2004: 150-159.

Mingana, Alfons. "Syriac influence on the style of the Kur'an". Bulletin of John Rylands Library. Manchester, 1927: 77-98. 
Mraizika, Florence. Le Coran décrée. Le défi de la science. Millau, Docteur Angélique, 2018.

Nöldeke, Theodor (Schwally, Friedrich; Bergsträßer, Gotthelf; Pretzl, Otto). The history of the Koran. Edited and translated by Wolfgang H. Behn. Leiden, London: Brill, 2013.

Prémare, Alfred-Louis de. Aux origines du Coran. Questions d'hier, approches d'aujourd'hui. Paris: Téraèdre, 2016.

Prémare, Alfred-Louis de. Les fondations de l'islam. Entre écriture et histoire. Paris: Seuil, 2002.

Santaella, Lúcia. Transcriar, transluzir, transluciferar. A teoria da tradução de Haroldo de Campos (Capítulo: 221-232). Leda Tenório da Mota (org.). Céu acima. São Paulo, Perspectiva, 2005.

Wansbrough, John. Quranic studies. Sources and methods of scriptural interpretation. Foreword, translations, and expanded notes by Andrew Rippin. Amherst, New York, 2004 (1 ${ }^{\mathrm{a}}$. ed. Oxford University Press, 1977).

Wansbrough, John. The sectarian milieu. Content and composition of Islamic salvation history. Oxford: Oxford University Press, 1978.

Xavier, Luiz Felipe. "O método histórico-crítico: origem, características e passos metódicos. Periódicos Rede Batista. V.3. n⿳010 1, Belo Horizonte, (2012). Disponível em: <http://periodicos.redebatista.edu.br/index.php/DP/article/ viewFile/84/67> . Acesso em: 28 set 2019.

Recebido em: 20/10/2019

Aceito em: 02/12/2019

Publicado em dezembro de 2019

Michel Sleiman. E-mail: sleiman.michel@gmail.com

ORCID: https://orcid.org/0000-0002-6050-6682 